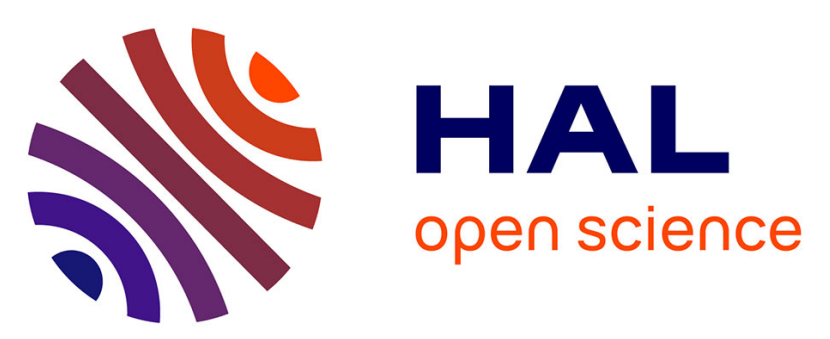

\title{
3D Electrical Resistivity Tomography to locate DNAPL contamination in an urban environment
}

Véronique Naudet, Jean-Christophe Gourry, Francis Mathieu, Jean-François Girard, Amélie Blondel, Alain Saada

\section{- To cite this version:}

Véronique Naudet, Jean-Christophe Gourry, Francis Mathieu, Jean-François Girard, Amélie Blondel, et al.. 3D Electrical Resistivity Tomography to locate DNAPL contamination in an urban environment. EAGE Near Surface 2011, 17th European Meeting of Environmental and Engineering Geophysics, Sep 2011, Leicester, United Kingdom. hal-00656587

\section{HAL Id: hal-00656587 https://hal-brgm.archives-ouvertes.fr/hal-00656587}

Submitted on 4 Jan 2013

HAL is a multi-disciplinary open access archive for the deposit and dissemination of scientific research documents, whether they are published or not. The documents may come from teaching and research institutions in France or abroad, or from public or private research centers.
L'archive ouverte pluridisciplinaire HAL, est destinée au dépôt et à la diffusion de documents scientifiques de niveau recherche, publiés ou non, émanant des établissements d'enseignement et de recherche français ou étrangers, des laboratoires publics ou privés. 


\author{
Naudet V., Gourry J.-C., Mathieu F., Girard J.F., Blondel A, Saada A. \\ BRGM , 3 avenue Claude Guillemin, F- 45060 Orleans, France
}

\begin{abstract}
This study presents results from electrical resistivity campaigns performed around a housing estate located downstream to an old coke tar site in France. This coke tar has been previously studied with geochemical analyses and geophysical prospections. The previous results have shown a possible migration of the contaminant plume toward the housing estate. As geophysical measurements are difficult to perform in such an urban environment, the electrical array has been deployed all around the housing estate with an innovative arrangement of surface electrodes in C-shape and acquisition geometries in order to achieve a real 3D imaging of the subsoil and locate the contaminant plume above the housing estate. The electrical resistivity data were inverted with the ERTLabTM 3D inversion software developed by Multi-Phase Technologies and Geostudi Astier. Results show, at the depth of the aquifer, a very conductive plume emanating from old tar ponds and a slag heap and spreading through the housing estate.
\end{abstract}

\title{
Introduction
}

Dense nonaqueous phase liquids (DNAPLs) are separate-phase hydrocarbon liquids that are denser than water, such as chlorinated solvents, wood preservative wastes, coal tar wastes, and pesticides. Groundwater can be contaminated by DNAPLs as they can be introduced into the subsurface by spills, uncontrolled releases and leaking storage and disposal facilities. Upon release, DNAPLs exist within the subsurface in either a free-phase or a residual form. The free-phase form spreads downward under the influence of gravity until they are distributed to such an extent that residual levels are attained and capillary trapping prevents further movement, or an impermeable layer is reached, at which point pooling and lateral spreading may occur. The residual form whereby becomes trapped in soil pores or rock fractures. Some of the more commonly-used techniques to locate DNAPL in the subsurface include use of monitoring wells, multi-level samplers, organic chemical analyses of soil samples at different depths, and soils borings or cone penetrometers to determine site stratigraphy. However, these techniques provide limited spatial information of the subsurface at discrete intervals leading to incomplete site assessments and inadequate remedial designs. In addition, some of them require drilling into the subsurface, which can result in the creation of new pathways for continued vertical migration of free-phase DNAPLs. Therefore, complementary tools given spatial information can help to reduce the ambiguity of interpretation and raise the probability of success. Non-invasive geophysical methods can be very useful as they survey large areas in a short time and at a lower cost than drilling techniques, they avoid infiltration of the contaminant to non-contaminated layers, and they enable more precise information between existing boreholes or piezometers, often separated by large distances. Over the last decades, a variety of geophysical methods have been proposed for the detection of DNAPLs in the shallow subsurface including ground-penetrating radar (Daniels et al., 1995; Bermejo et al., 1997; Cassidy, 2008), resistivity methods (Newmark et al. 1998, Benson et al., 1997; Atekwana et al., 2005, Chambers et al. 2010), induced polarization (Chambers et al., 2005) and self-potential measurements (e.g., Minsley et al., 2007).

In this paper, we present two electrical resistivity campaigns performed around a housing estate located downstream an old coke tar site. The first campaign consisted in twelve 2D profiles with an electrode spacing of $5 \mathrm{~m}$ acquired in 2006 and 2008. The second campaign consisted in 3D crossprofiles acquisitions with a C-shape configuration and an electrode spacing of $10 \mathrm{~m}$ all around the housing estate. The originality of this study relies on the innovative arrangement of surface electrodes for the 2010 campaign and the processing procedure used to increase the resolution of the resistivity survey and therefore to better determine the contaminant plume extension under the housing estate. 


\section{Near Surface}

\section{Site presentation}

The studied site is located downstream a former coke factory (North of France) that operated from 1921 to 1973. During this period, the factory produced 100000 tons of coke, 4000 tons of crude tar, 1100 tons of ammonium sulfate and 400 tons of benzoyl. Since closure, the surface structures have been demolished and it was estimated that 2000 to 20000 tons of acid tar, a Dense Non-Aqueous Phase Liquid (DNAPL), as well as $3.10^{5} \mathrm{~m}^{3}$ of process water containing phenols and ammonium sulfate, were stored in two tar ponds. These tar ponds and the slag heap (fig. 1) constitute the main contaminant sources. One of the tar pond was emptied in 1992 and the other in 2004.

The geology of the site comprises a 4 to $6 \mathrm{~m}$ thick layer of quaternary silt and of tertiary clayey-sand formation due to chalk alteration above a $50 \mathrm{~m}$ thick chalk secondary formation. The chalk aquifer is present at a depth varying between 25 to $30 \mathrm{~m}$ depending on the season. The impermeable substratum consists of green shale. The regional groundwater flow is predominantly northward. Since 1991, the tar ponds impact on the groundwater has been evidence and a monitoring borehole array has been installed inside and around the old coke tar (fig.1). Geochemical analyses show elevated concentration of PAH15 and BTEX around the tar ponds (fig.1). The hydraulic conductivity of the aquifer is very weak $\left(\mathrm{K}=10^{-6} \mathrm{~m} / \mathrm{s}\right)$, but possible fractures inside the chalk have been mentioned and the pollution sources, made of acid tar, may also have weathered the lower part of the aquifer close to the source zone, improving the downward migration of coal tar.

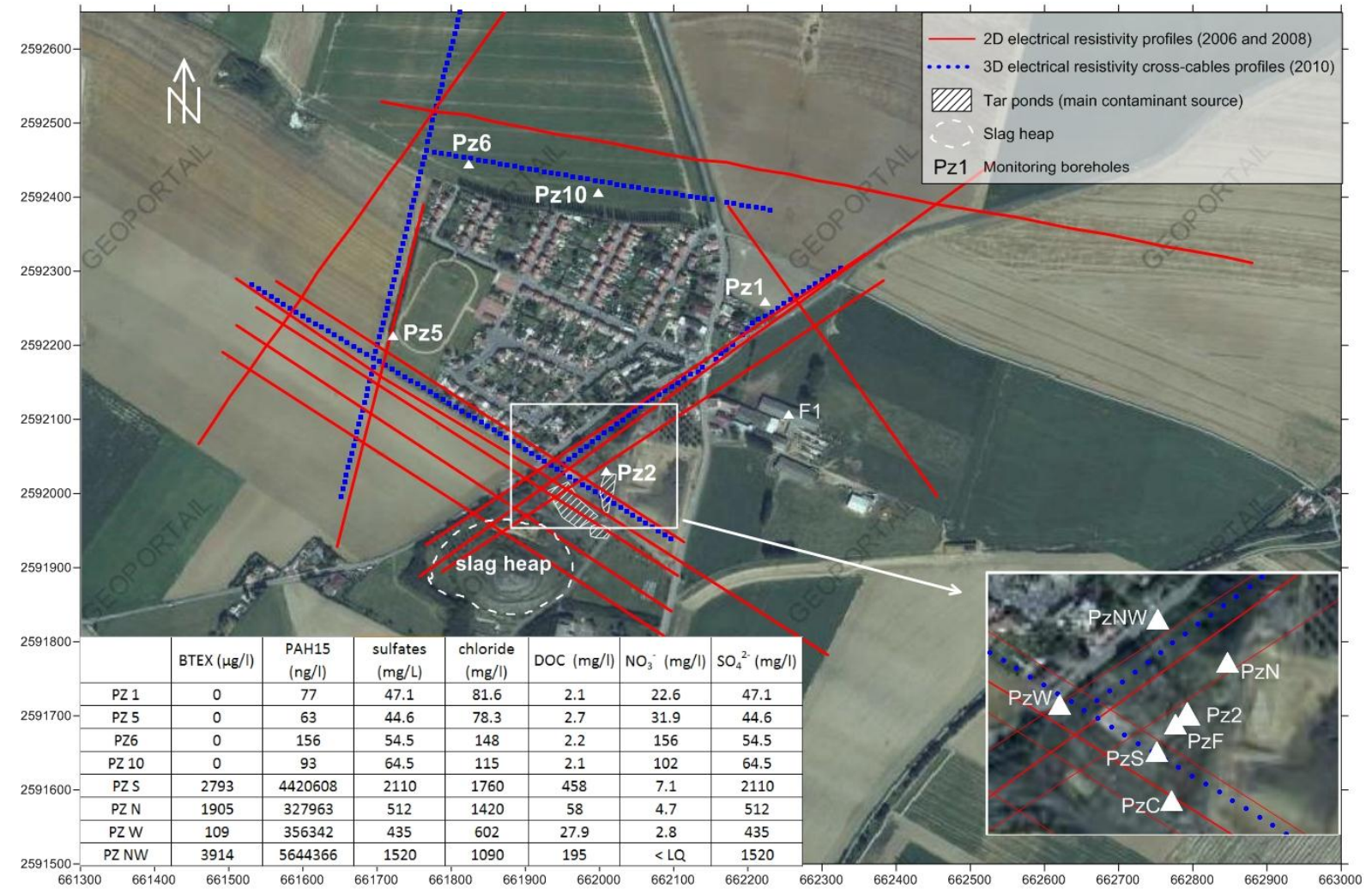

Figure 1 Location of the studied area. The produced wastes of the coal factor were stored in a slag heap and the coal tar inside tar ponds mixed with acids. Red lines indicate the location of the twelve $2 D$ profiles $(5 \mathrm{~m}$ electrode spacing) and blue lines the location of L-shape electrodes used to perform $3 D$ acquisition $(10 \mathrm{~m}$ electrode spacing). Table presents some geochemical analyses of June 2009.

A housing estate is located just at the north of the contaminated site in the direction of the groundwater flow and no borehole has yet been realized in this zone. In 2009, the piezometer PzNW has been impacted by coal tar, suggesting an extension of the contaminant plume (fig.1). As many boreholes for agriculture are present in this zone with drinking water borehole tree kilometers away, it was crucial to determine the extension of the contaminant plume under the housing estate in order to help in the location of future boreholes. 


\section{Data acquisition and processing}

Base on a previous 2D electrical resistivity measurements performed in 2006 and 2008 all around the housing estate, we performed in October 2010 a 3D electrical resistivity campaign. To achieve a real $3 \mathrm{D}$ imaging of the subsoil, the specific working conditions lead to assume non-conventional geometries of the electrodes layout to assess if the contaminant plume spreads under the housing estate. A number of 226 electrodes were installed all around the housing estate each 10 meters along 4 straight profiles (fig. 1). Acquisitions were performed using a C-shape geometry of the electrodes (the electrodes can be approximately divided into two branches). A pole-dipole configuration in common cable (transmitting and receiving electrodes belonging to the same branch) and cross-cables (all possible combinations where transmitting and receiving dipoles are not on the same line) has been used with the "infinite" electrode placed $2 \mathrm{~km}$ away in the north-west direction. After data filtering on the geometric factor $(<15000)$ and on the rms error during an injection cycle $(<3 \%)$ at least $3 \%$ of the data have been removed leading to 33271 measurements used for the inversion. Data were processed using the ERTLab ${ }^{\mathrm{TM}}$ 3D inversion software developed by Multi-Phase Technologies and Geostudi Astier. This code uses a Finite Elements (FEM) approach to model the subsoil by adopting mesh of hexaedrons to correctly incorporate complex terrain topography. Therefore, data-sets collected 2D profiles, 3D surface grids, boreholes, surface-to-hole arrays, or any 2D or 3D four-electrode array can be inverted (Zhou and Greenhalgh, 2001). The reliable and robust algorithm for 3D resistivity inversion assures accuracy and convergence, even when high levels of noise are present in the dataset. The inversion procedure is based on a smoothness constrained least-squared algorithm (LaBrecque et al., 1995) with a Tikhonov model regularization. Noise is appropriately managed using a data weighting algorithm (Morelli and LaBrecque, 1996). A 5\% standard deviation estimate for noise was assumed to invert the data set with a robust inversion. The data-set was inverted by using a 10x10x20 meters mesh size and starting from an initial homogeneous model of $43 \mathrm{Ohm} . \mathrm{m}$. The model comprises 150000 cells that require around 5 hours on a standard laptop to be completed.

\section{Results}

Figure 2.a shows electrical resistivity map at the depth of the aquifer obtained with the twelve 2D electrical profiles acquired in 2006 and 2008 all around the housing estate. These data have been inverted with Res2dInv (Loke 2004) and then interpolated in 3D with surfer. A conductive zone with electrical resistivity values below $20 \mathrm{Ohm} . \mathrm{m}$ was clearly identified below the contaminant sources (slag heap and tar ponds) with an extension towards the north. This interpolated map also suggested a possible spreading of the contaminant plume towards the housing estate. Nevertheless, these 2D data were not able to image below the housing estate. To achieve a real 3D imaging of the subsoil below the housing estate, a non-conventional geometry of the electrodes have been used in L-shape and Cshape in October 2010.

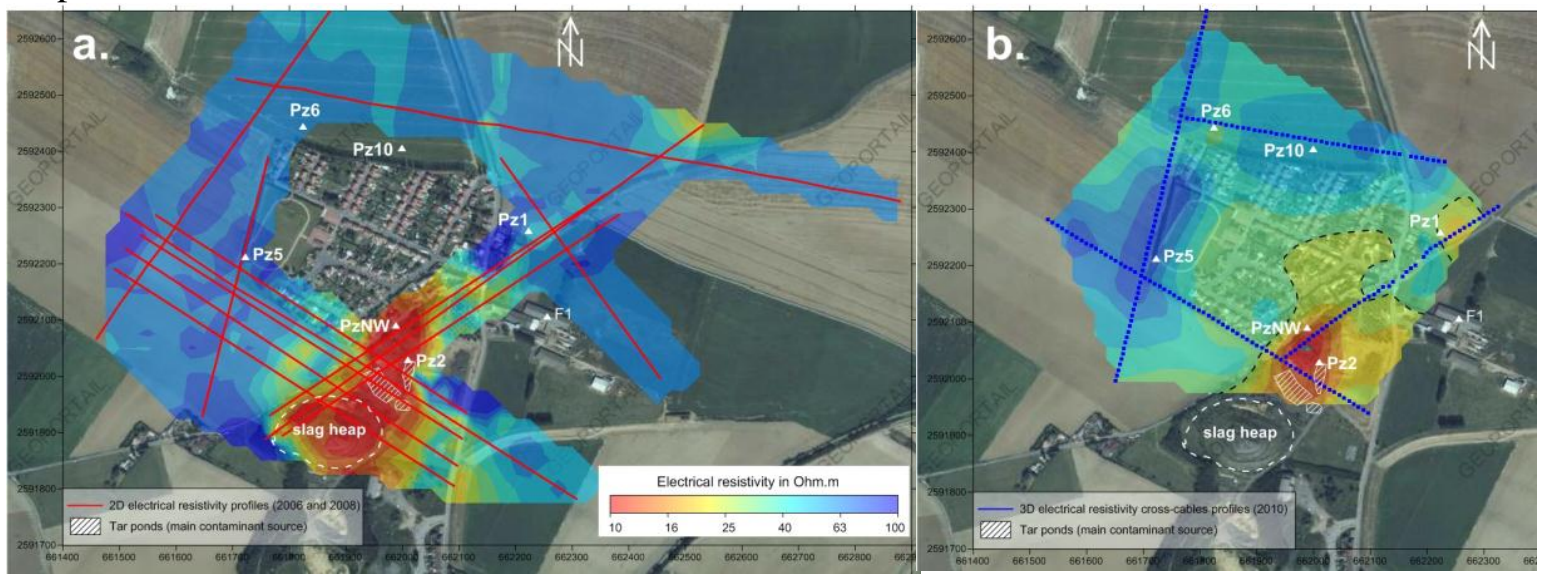

Figure 2 a. Electrical resistivity distribution between 20-30 m depth obtained with a 3D interpolation of $2 \mathrm{D}$ inverted data acquired in 2006 and 2008. b. Electrical resistivity distributing at 20-30 $\mathrm{m}$ depth obtained with $3 D$ inverted data acquired in October 2010. 
The map obtained at the same depth with the 3D data acquired in 2010 and inverted with the ERTLab $^{\mathrm{TM}}$ 3D inversion software is presented on figure 2.b with the same electrical scale color. The resistivity distribution obtained is consistent with previous geophysical measurements (fig.2.a) and also show the same very conductive body close to the tar ponds. A north extension of the conductive zone is visible with a decreasing of the conductive property. On figure 2.b. the black dashed line equals to $30 \mathrm{Ohm} . \mathrm{m}$ could reflect the contaminant plume. This result can indicate a migration of the contaminant plume in the aquifer towards the north direction. Initially, the plume is relatively shallow concentrated around the sources, then, it spreads more widely downstream. Close to the borehole Pz1, a small conductive zone also appears, suggesting a possible contamination through fractures.

As this is a non-common acquisition configuration, the effectiveness of the $3 \mathrm{D}$ coverage has been studied with a sensitivity analysis. Such sensitivity analysis allows also investigating the resolution resulting from the geometry of electrodes. Resolution is a complex function of numerous factors (e.g. electrode layout, measurement schedule, data quality, imaging algorithm, electrical conductivity distribution) and, in general, varies significantly across the image plane. The sensitivity analysis performed on some selected quadrupoles shows that, at the aquifer depth, a satisfactory degree of sensitivity can be achieved not only below the electrodes but also below the housing estate.

\section{Conclusions}

A contaminant plume due to a former coke factory that operated from 1921 to 1973 is suspected to spread towards a housing estate according to 2D electrical resistivity profiles performed in 2006 and 2008 all around the housing estate and geochemical analyses performed in 2009. The new electrical resistivity campaign performed in 2010 consisted in innovative 3D electrical resistivity acquisitions with a C-shape configuration of the electrodes installed all around the housing estate. This original electrodes arrangement and the processing procedure used to increase the resolution of the resistivity survey helped us to better determine the contaminant plume extension under the housing estate. These geophysical results are of high interest for the placement of a new monitoring borehole planned to be drilled in 2011 in the housing estate.

\section{Acknowledgements}

The authors acknowledge the financial support of ADEME (Agence De l'Environnement et de la Maitrise de l'Energie) for this study (agreement $\left.n^{\circ} 0572 \mathrm{C} 0064\right)$.

\section{References}

Atekwana, E.A., Atekwana, E., Legall, F.D. and Krishnamurthy, R.V. [2005] Biodegradation and mineral weathering controls on bulk electrical conductivity in a shallow hydrocarbon contaminated aquifer. Journal of Contaminant Hydrology 80(3-4), 149-167.

Benson, A.K., Payne, K.L. and Stubben, M.A. [1997] Mapping groundwater contamination using dc resistivity and VLF geophysical methods - a case study. Geophysics 62, 80-86.

Bermejo, J.L., Sauck, W.A. and Atekwana, E.A. [1997] Geophysical discovery of a new LNAPL plume at the former Wurtsmith AFB, Oscoda, Michigan, Ground Water Monitoring \& Remediation 17, 131-137.

Cassidy, N.J. [2008] GPR attenuation and scattering in a mature hydrocarbon spill: a modeling study. Vadose Zone Journal, 7, 140-159.

Chambers, J.E, Meldrum, P.I., Ogilvy; R.D. and Wilkinson, P.B. [2005] Characterisation of a NAPLcontaminated former quarry site using electrical impedance tomography, Near Surface Geophysics, 79-90.

Chambers, J.E., Wilkinson, P.B., Wealthall, G.P., Loke, M.H., Dearden, R., Wilson, R., Allen, D. and Ogilvy, R.D. [2010] Hydrogeophysical imaging of deposit heterogeneity and groundwater 
chemistry changes during DNAPL source zone bioremediation, Journal of Contaminant Hydrology 118, 43-61

Daniels, J., Roberts, R. and Vendl, M. [1995] Ground penetrating radar for the detection of liquid contaminants. J. Appl. Geophys. 33, 195-207.

LaBrecque D.J., Morelli, G., Daily, B., Ramirez A. and Lundegard P. [1995] Occam's inversion of 3D ERT data. In: B. Spies, Editor, Three-Dimensional Electromagnetics, SEG, Tulsa, 575-590.

Loke, M. H. [2004] Electrical Imaging Surveys for Environmental and Engineering Studies. Tutorial: 2-D and 3-D Electrical Imaging Surveys. www.geoelectrical.com.

Minsley, B. J., Sogade, J. and Morgan, F.D. [2007] Three-dimensional self-potential inversion for subsurface DNAPL contaminant detection at the Savannah River Site, South Carolina, Water Resour. Res., 43, W04429, doi:10.1029/2005WR003996.

Morelli, G. and LaBrecque, D.J. [1996], Advances in ERT inverse modelling, Eur. J. Environ. Eng. Geophys. 1, 171-186.

Newmark, R., Daily, W., Kyle, K and Ramirez, A. [1998] Monitoring DNAPL pumping using integrated geophysical techniques. Journal of Environmental and Engineering Geophysics, 3(1), 713 ,

Zhou, B. and Greenhalgh, S. [2001] Finite element three-dimensional direct current resistivity modelling: accuracy and efficiency considerations, Geophys. J. Int. 145, 679-688. 